DOI: https://doi.org/10.32839/2304-5809/2021-3-91-31

УДК 75.071.1(477.83/.86)(092)

Савчин Г.В., Сивак I.B.

Дрогобицький державний педагогічний університет імені Івана Франка

\title{
ТВОРЧІСТЬ ГРИГОРІЯ ПІЗНАКА В КОНТЕКСТІ НАЇВНОГО МАЛЯРСТВА
}

\begin{abstract}
Анотація. У статті наголошено, що осмислення споконвічних цінностей, звернення до національної свідомості, культурної ідентичності - це шлях збереження української нації у сучасному глобалізованому світі. Показано, що важливим чинником націозбереження є наївне мистецтво. В галицькому наїві втілилися християнська віра, світосприйняття, ментальність та традиції українського народу. Проте багатогранний мистецький доробок митців-самоуків Галичини ХХ ст. ще не став об'єктом дослідження мистецтвознавства. У статті висвітлено наївне мистецтво в змісті сучасної культури України як особливого виду народної художньої творчості; охарактеризовано художньо-стилістичні особливості творів народного наїву Галичини другої половини XX - початку XXI ст.; проаналізовано життевий шлях та творчий доробок Григорія Пізнака крізь призму наїву.
\end{abstract}

Ключові слова: українська культура, ментальність, наївне мистецтво, Галичина, малярство, ікономалярство, митець-самоук.

Savchyn Halyna, Sivak Irina

Drohobych Ivan Franko State Pedagogical University

\section{CREATIVE WORK OF HRYHORII PIZNAK IN THE CONTEXT OF NAIVE PAINTING ART}

Summary. Understanding of eternal values, appeal to national consciousness, cultural identity - this is the way to preserve the nation in today's globalized world. An important factor in preserving the Ukrainian nation is naive art. The Christian faith, worldview, mentality and traditions of the Ukrainian people were embodied in the Galician naive art. In the article we highlighted naive art in the sense of modern culture of Ukraine as a special kind of folk art. Characterized the artistic and stylistic features of the works of folk naivety of Galicia in the second half of the XX ${ }^{\text {th }}$ century - early XXI ${ }^{\text {st }}$ century. Explored the artistic heritage of folk artist Gregory Piznaka. Direct communication with the artist, with fellow villagers and admirers of his work made it possible to chronologically build the life of the artist and identify the main creative achievements. Personal impressions and emotional experiences became the basis of Hryhoriy Piznak's work. Analysis of the artist's creative work allows us to identify two lines of creativity associated with the development of the artist's new techniques and genres: 1) the tendency to create landscapes and thematic compositions; 2) sacred painting. In the first line of work, the artist successfully combines landscape and images of human figures, creating a rich in color, bright and expressive image of the Ukrainian countryside. The sincere, somewhat naive artistic language of the artist's works finds a soulful response in the viewer, which brings G. Piznak's works closer to the folk picture. The artist's sacred painting organically combines easel iconography and plot-thematic painting, which is a characteristic feature of Ukrainian sacred painting of the XX ${ }^{\text {th }}$ century. G. Piznak, like Galician self-taught artists, used canonical images and plots, but supplemented them with images of the environment, landscape or interior. As a result, Hryhoriy Piznak embodied his own understanding of sacred art in icon painting. Summarizing the above, we can confidently say that Hryhoriy Kyrylovych Piznak is a bright representative of Galician naive art of the second half of the $\mathrm{XX}^{\text {th }}$ century - the beginning of the XXI ${ }^{\text {st }}$ century, whose creative work remains unexplored, which opens the prospect of a new perspective on Galician folk painting of this period.

Keywords: Ukrainian culture, mentality, naive art, Galicia, painting, icon painting, self-taught artist.

$\Pi^{2}$ остановка проблеми. Реалії сучасного життя українського суспільства дають підстави стверджувати про початок нового соціально-історичного етапу розвитку України, що вимагає перегляду усталених норм та розробки новітніх стратегій розвитку соціум, які би задовольняли духовні потреби як кожного громадянина України, так й української нащї в цілому.

Одвічним носієм цінностей та прагнень українського народу $є$ культура України, яка засвідчуе цілому світу своерідність української національної ментальності, народного світосприйняття та самоідентифікації.

Самобутність українського народу в естетичному, культурологічному, фрілософрському, релігієзнавчому аспектах яскраво репрезентуе фе-номен української культури - наївне мистецтво. М. Приймаченко, К. Білокур, Г. Собачко-Шостак, I. Сколоздра, Т. Пата, Н. Білокінь, П. Ярмоленко, Г. Ксьондз та інші українські непрофресійні митці-самоуки створили фантастичні роботи.
Наївне мистецтво України привертає увагу сучасних дослідників, мистецтвознавців, митців та шанувальників. Проте, незважаючи на низку досліджень в галузі мистецтвознавства за останні роки, наївне мистецтво Галичини є малодослідженим явищем української культури XX століття. Публікації в переважній більшості науковців (О. Голубця, Т. Гуменюк, Т. Кара-Васильевої, М. Мусій, О. Новицької, О. Роготченко, Р. Шмагала, В. Цісарик та ін.) висвітлюють творчий доробок професійних художників Західної України. Творчість окремих народних художників XX століття досліджували Я. Нановський, Г. Островський, Т. Пошивайло-Марченко, О. Ріпко, С. Чехович.

Дослідження доводять, що наївне мистецтво Галичини є яскравим френоменом української культури ХХ століття. Воно існувало поряд 3 «провладним» соцреалізмом, однак пропагувало відмінну систему цінностей та зумовило появу народних митців. Це зумовлюе необхідність 
цілеспрямованих наукових досліджень 3 метою мистецтвознавчого аналізу, узагальнення та систематизації мистецького доробку галицьких митців-самоуків. Актуальною позицією у цьому плані постає вивчення творчості митця-самоука зі Старосамбіршини Григорія Кириловича Пізнака.

Аналіз останніх досліджень і публікацій. Серед періодичних видань, які висвітлювали життя та творчість Григорія Пізнака як митця, варто назвати «Голос Прикарпаття», «Високий замок». В книзі Левка Паращака «З покоління незламних» [3] згадуеться про Григорія Пізнака та його родину. Огляд статей, інтерв'ю з Г. Пізнаком, розповіді односельців та відгуки пошановувачів таланту художника дають повне право віднести їх до важливих джерел дослідження творчості митця. Аналіз цих джерел дозволяє не лише вивчити постать Г. Пізнака як митця-самоука, а й дослідити історію українського народу західного регіону, на фоні якої відбувалася творча діяльність митця, оскільки складна політична ситуація в Україні в XX столітті безпосередньо вплинула на життя та творчість Г. К. Пізнака.

Мета статті - дослідити творчість Г. К. Пізнака в контексті наївного мистецтва Галичини другої половини XX ст. - поч. XXI ст.

Виклад основного матеріалу. Наївне мистецтво як новий напрям розвитку мистецтва виник на початку XX століття. Цей період розвитку культури охарактеризувався активним розквітом образотворчого мистецтва та появою різноманітних авангардних мистецьких течій (абстракціонізм, примітивізм, кубізм, футуризм, сюрреалізм тощо), які заперечували усталені форми і традиціï. Це сприяло розробленню нових художніх засобів та способів формотворень в мистецтві.

На теренах України структурна зміна, якісна трансформація фольклорної архаїки, народного мистецтва у творчих роботах авангардистів К. Малевича, М. Бойчука, О. Архипенка, Г. Нарбута, В. Кричевського та інших активізувало інтерес народної картини та творів народних художників.

Аналіз наукової літератури дає змогу стверджувати, що на даний час немає єдиного визначення наївного мистецтва. В довідковій літературі (словниках та енциклопедіях) дефініція поняття «наївне мистецтво» значно різниться Існуе два основні підходи визначення цього поняття: 1) наївне мистецтво є протиставленням профресійному мистецтву; 2) під «наївним мистецтвом» розуміють творчість митців без академічної освіти на основі власного світосприйняття та світорозуміння [2].

Українське наївне малярство увібрало в себе фольклор, вірування та міфи прадавніх часів. Для робіт митців цього напряму образотворчого мистецтва характерні непропорційність образів, недотримання законів композиції, повна відсутність або слабо виражена перспектива, плавність та округлість форм, декоративність, своєрідний колорит [1].

Народне мистецтво Галичина в другій половині XX століття розвивалось в умовах тоталітарного режиму Радянського Союзу. За таких політичних умов українське населення Західної України прагнуло зберегти свою національну ідентичність. Важливим чинником націозбере- ження стало малярство, яке в західному регіоні цілісно було поєднано із релігійним життям народу, не дивлячись на радянську пропаганду та утиск з боку влади.

Яскравим репрезентатором народного наїву Галичини другої половини XX ст. - початку XXI ст. є Григорій Кирилович Пізнак.

Він народився 15 лютого 1930 року на Старосамбірщині в селі Мшанець в багатодітній сім'ї, в який виховувалось семеро дітей. Родина Пізнаків пережила важки випробування 3 приходом радянської влади. Рідний брат Григорія Пизнака Іван брав активну участь у складі УПА. Його у 1945 році заарештували та відправили у Іркутську область. Згодом й всю сім'ю Пізнаків у 1946 році вивезли у Сибір.

Григорію Пізнаку вдалось уникнути арешту. Він майже рік переховувався у рідні. Проте парубок продовжував підтримувати народний спротив, допомагав повстанцям, збирав у людей продукти та відносив у ліс для воїнів УПА. Однак у 1946 рощі його схопили та присудили вислання. Спочатку була Східна Україна, через пів року Григорія вивезли у Мордовію, звідси 17-літнього хлопчину відправили у Казахстан, а потім в Кемеровську область, в Росію. Митець пригадує, що то були страшні часи. Але попри всі випробування Григорій Пізнак знаходив час малювати, щоб відволіктись від страшної реальності. Його малюнки побачив репресований бактеріолог з України Микола Щербак. Він познайомив хлопчину з Юхимом Залізняком, який взяв талановитого парубка у художню майстерню при радіозаводі. Тут юнак зустрівся 3 художниками Василем Турецьким 3 Буковини та Олександром Корецьким 3 Волині, які допомогли хлопчинові розвинути художні задатки. Загалом Григорій Пізнак у сталінських таборах провів 7 років 9 місяців і 3 дні.

У 1955 році на Різдво Григорій Пізнак повернувся на українську землю. Проте йому не дозволили поселитись в рідному селі, тому він влаштувався на роботу мотористом у клубі сусіднього села Стрілки.

Новим етапом в духовному становленні художника стала зустріч з Б. Жидиком, директором школи-інтернату в Стрілках. Він запросив Г. Пізнака працювати вчителем малювання у навчальному закладі, не дивлячись на те, що той не мав педагогічної освіти. У школі-інтернаті Григорій розкрив свій не тільки мистецький талант, але й педагогічний. Він 11 років пропрацював в цьому навчальному закладі.

Весь час Григорій Кирилович Пізнак малював. Його творчий доробок вражає. Це сюжетні картини, ікони, настінні розписи, копії відомих робіт.

Аналіз творчого доробку митця дає змогу виділити дві лінії творчості, пов'язані з освоєнням художника нових жанрів та технік. Одна 3 ліній творчості Григорія Пізнака характеризуеться тяжінням до творення пейзажів та сюжетно-тематичних композицій, які породжені сприйняттям реальності або перейняті з українського етносу. Щира, дещо наївна художня мова робіт художника знаходить душевний відгук у глядача, що наближує роботи Г. Пізнака до народної картини. У його картинах «Після дощу» (іл. 1), «Ой звідси гора, звідси друга...» (іл. 2), «Ой рано зілля купала", "Біля криниці», «Пастухи» створені не 
лише сюжетні моменти, а вимальовуеться повноцінна оповідь, яка доповнена деталями та акцентами. Живописні роботи насичені яскравими барвами. Митець вдало поєднує пейзаж і зображення фрігур людей, утворюючи насичений в кольорі, яскравий та виразний образ українського села. Змістове наповнення живописних робіт дає змогу стверджувати про ідеально-франтазійне відтворення реального світу в роботах митця. Правдиве відтворення побуту, одягу поєдналось 3 настроєвістю, певною стилізацією об'єктів.

Дві останні роботи Г. Пізнака «Сім'я Стицьковичів» (іл. 3), «Похорон перед засланням в Сибір» (іл. 4) дещо відрізняються від попередніх живописних композицій. Існуе разючий контраст між роботами, які передають красу природи і людей, та цими картинами, які присвячені трагічним подіям в житті родини митця.

На картині "Сім'я Стицьковичів» зображено арешт сім'ї Стицьковичів працівниками НКВС у с. Мшанець у 1940 році. Друга робота «Похорон перед засланням в Сибір» передає трагічну подію, яку пережила родина Пізнаків у 1946 році. На полотні зображено похорон 3-річної сестри Григорія Пізнака. Це сталось в той день, коли усю сім'ю мали виселити у Сибір. На картині показано, як працівники НКВС оточили маленьку похоронну процесію, не допускаючи односельців до сім’ї Пізнаків. Для художника ця робота була важкою в духовному сенсі. Він згадує, що при написанні картини він переживав нестерпний біль знов і знов: «Кожен мазок пензлика неначе ранив серце і воно кровоточило, немов би все це відбувається у цю хвилину. Це - моя Голгота». Сюжет цих картин передає жорстокість, трагедію, глибинне горе сім'ї. Пластична мова, колорит, лінії вдало підкреслюють сюжет. Постаті людей, вираз облич, рухи надзвичайно емоційно передають весь трагізм, біль та скорботу митця.

Зрілість творчого зростання Григорія Пізнака знайшла своє відображення у релігійному малярстві. У сакральному малярстві митця Григорія Пізнака органічно поєднались станковий іконопис i сюжетно-тематичне малярство, що є характерною рисою українського сакрального мистецтва XX століття.

Не маючи відповідної освіти, Григорію Кириловичу Пізнаку доводилось самотужки освоювати канони іконопису. В результаті в іконопис-

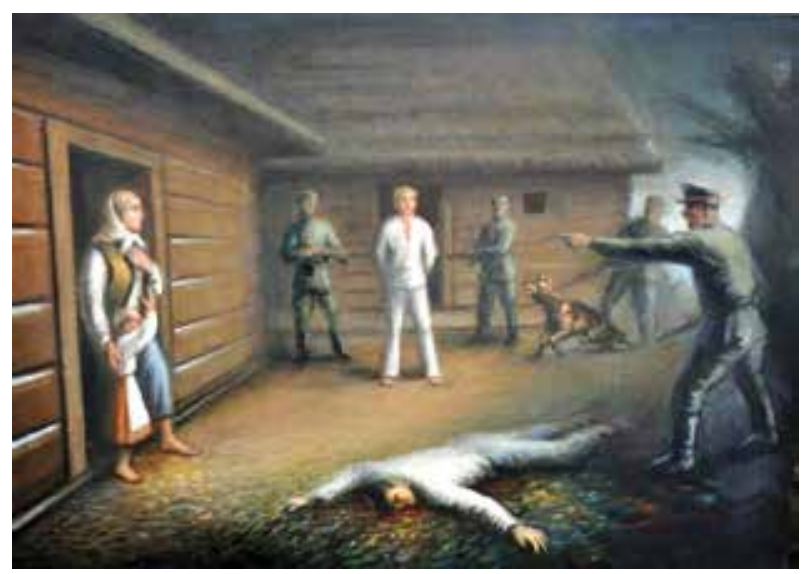

Іл. 3. «Сім'я Стицьковичів», 2014 р., грунтоване ДВП, олія

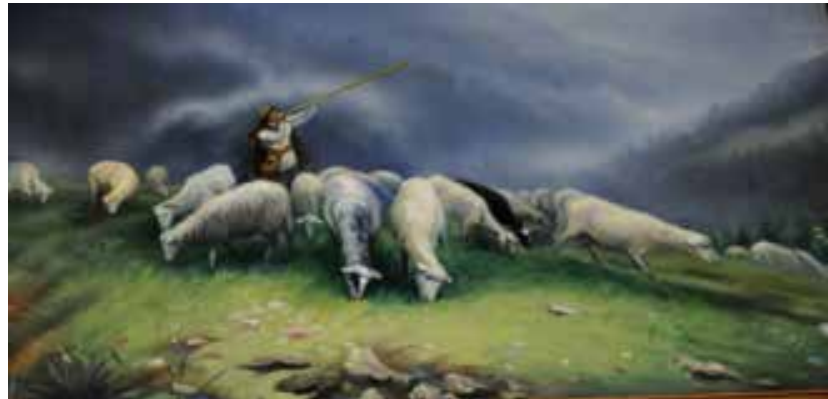

Іл. 1. «Після дощу», 1974 р., полотно, олія

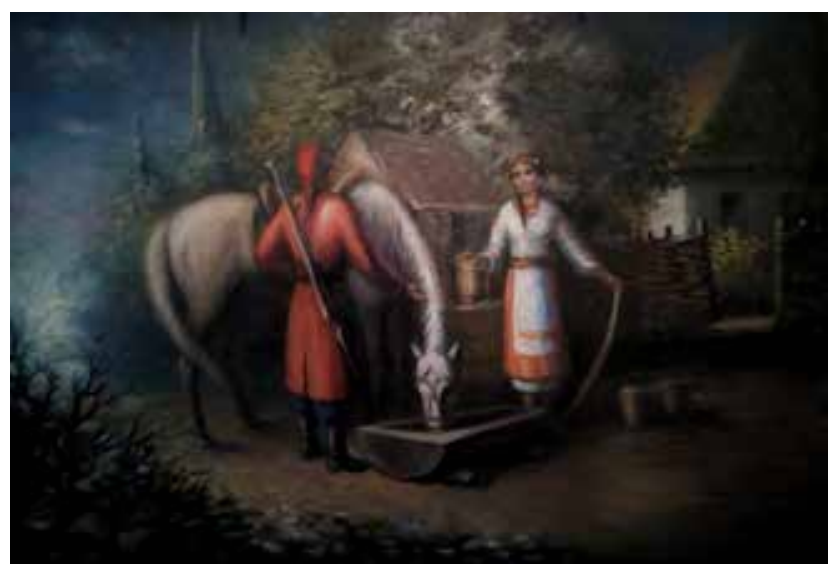

Іл. 2. «Ой звідси гора, звідси друга...», 2019 р., грунтоване ДВП, олія

ному малярстві Григорія Пізнака втілено його власне розуміння сакрального мистецтва.

Ікони «Покрови Пресвятої Богородиці» (іл. 5) та «Розп'яття» (іл. 6), написані Г. Пізнаком у 1993 році для каплички в с. Стрілки, яскраво відображають тенденцї галицького сакрального малярства XX століття. Дослідниця Н. Руско, використовуе для таких типових робіт термін «іконокартини» [4]. Галицькі митці використовували канонічні образи й сюжети, але доповнювали їх зображенням пейзажу або інтер'єру. Завдяки цьому ікона (або як говорять на Галичині «образ») набувала більшої ілюстративності, привертала увагу вірян актуалізацією образів й наближенням їх до умов України. Колорит «Розп'яття» передає відчуття напруженість і покаяння за грі-

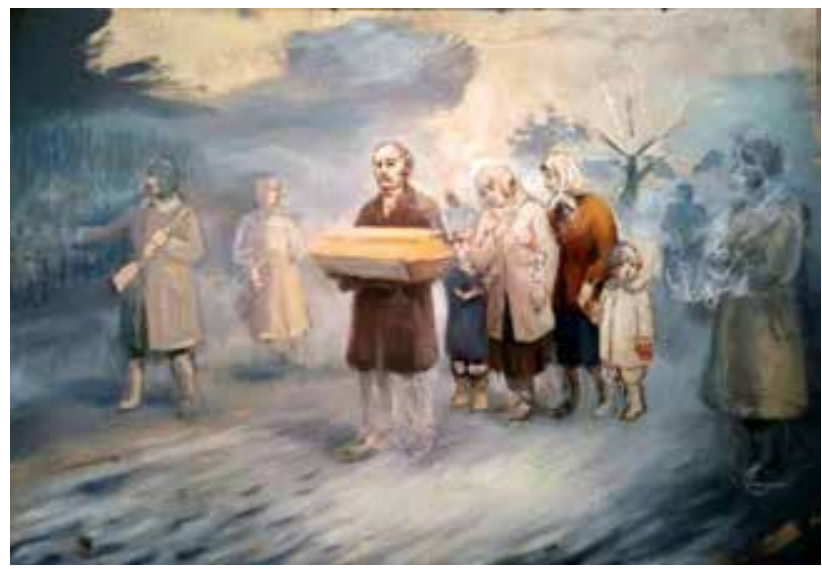

Іл. 4. «Похорон перед засланням в Сибір», 2019 р., грунтоване ДВП, олія 


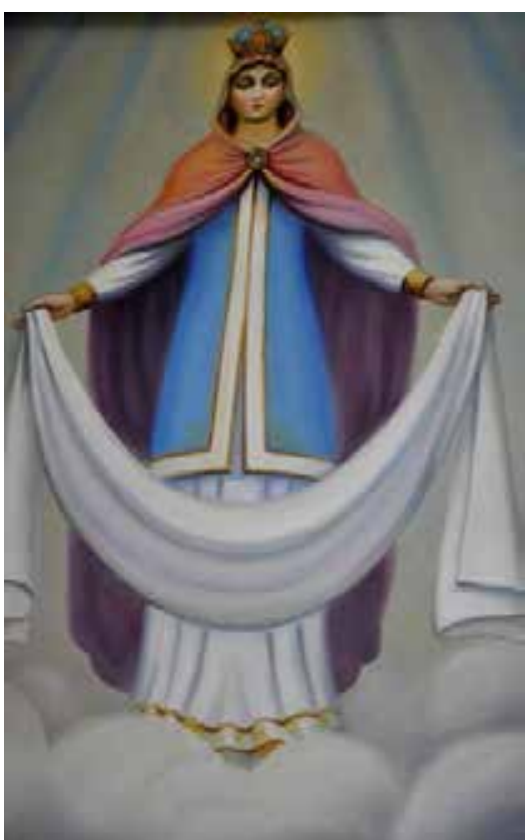

Іл. 5. «Покрова Пресвятої Богородиці»

хи, а «Покрови Пресвятої Богородиці» - спокою та надіє на спасіння.

Загалом для сакрального малярства Г. Пізнака характерна одухотвореність образів, стрункі постаті персонажів, плавність ліній, гармонійний колорит.

Ікони та іконостаси Григорія Пізнака в с. Стрілки, с. Мшанець, с. Топільниця, с. Головецько, с. Смерічка, с. Верхній Лужок, с. Бусовисько, с. Лаврів, с. Велика Лінина, с. Береги, с. Бабино та інші засвідчують профресійні якості та великий творчий потенціал народного митця.

Висновки. Сучасність вимагає від українського соціуму вирішення низки проблем, які охопили основні сфери його життедіяльності (духовну, матеріальну, соціокультурну та сощіально-політичну).

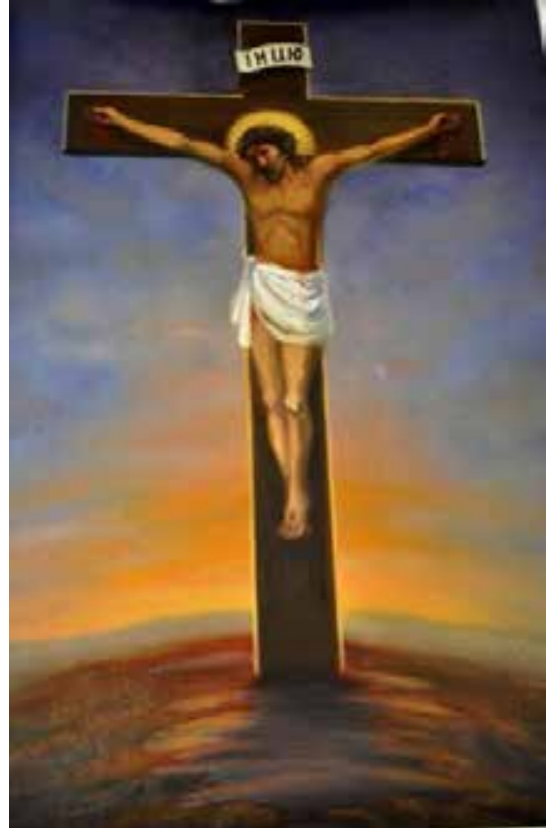

Іл. 6. «Розп'яття»

Ми глибоко переконані, що для подолання кризового стану необхідно звернутися до культурної спадщини українського народу.

Вважаємо, що в контексті актуалізації досліджень регіональних осередків народної творчості вивчення мистецької спадщини народних митців-самоуків є особливо важливим для розуміння першооснов народного малярства, його художньо-образної мови та засобів вираження.

Підсумовуючи викладене, можемо впевнено стверджувати, що Григорій Кирилович Пізнак яскравий представник галицького наїву другої половини XX ст. - початку XXI ст., творчий доробок якого залишаються недослідженими, що відкриває перспективу нового ракурсу вивчення народного малярства Галичини зазначеного періоду.

\section{Список літератури:}

1. Анучина Л. В. Роздуми про феномен народного малярства (спроба культурологічного аналізу). Вісник Національного університету "Юридична академія України імені Ярослава Мудрого". Серія : Філособія, ббілособбія права, політологія, соціологія. 2015. № 2. С. 68-77.

2. Богачёва Ю. Наивное искусство как манифестация сакрального в современной культуре. Докса. 2018. Вип. 2. C. 141-148. URL: http://nbuv.gov.ua/UJRN/ (дата звернення: 25.02.2021).

3. Паращак Л. 3 покоління незламних : оповідання. Львів : Афріша, 2011. 160 с.

4. Руско Н. Іконописна спадщина Галичини кінця XIX - початку XX століття. Світогляд - Філософбія - Релігія. 2014. Вип. 6. С. 129-137.

\section{References:}

1. Anuchyna L. V. (2015) Rozdumy pro fenomen narodnogo malyarstva (sproba kulturologichnogo analizu) [Reflections on the phenomenon of folk painting (an attempt at culturological analysis)]. Visnyk Nacionalnogo universytetu "Yurydychna akademiya Ukrayiny imeni Yaroslava Mudrogo". Ser.: Filosofiya, filosofiya prava, politologiya, sociologiya, no. 2, pp. 68-77.

2. Bogachëva Yu. (2018) Nayvnoe yskusstvo kak manyfestacyya sakralnogo v sovremennoj kulture [Naive art as a manifestation of the sacred in modern culture]. Doksa, vol. 2, pp. 141-148. Available at: http://nbuv.gov.ua/UJRN/ (accessed 25 February 2021).

3. Parashhak L. (2011) Z okolinnya nezlamnyx: opovidannya [From the generation of the unbreakable: a story]. Lviv: Afisha. (in Ukrainian)

4. Rusko N. (2014) Ikonopysna spadshhyna Galychyny kincya XIX - pochatku XX stolittya [Iconic heritage of Galicia in the late XIX - early XX centuries]. Svitoglyad - Filosofiya-Religiya, vol. 6, pp. 129-137. 